\title{
Distribution of Calbindin D28k-like Immunoreactivity (LI) in the Monkey Ventral Horn: Do Renshaw Cells Contain Calbindin D28k-LI?
}

\author{
Ulf Arvidsson,' Brun Ulfhake, ${ }^{1}$ Staffan Cullheim, ${ }^{1}$ Vania Ramírez, ${ }^{1}$ Oleg Shupliakov, ${ }^{1,3}$ and Tomas Hökfelt ${ }^{2}$ \\ Departments of ${ }^{1}$ Anatomy, ${ }^{2}$ Histology and Neurobiology, and ${ }^{3}$ Nobelinstitute for Neurophysiology, Karolinska Institute, \\ S-10401 Stockholm, Sweden
}

\begin{abstract}
By use of indirect immunofluorescence and peroxidase-antiperoxidase immunohistochemistry, we show that the monkey (Macaca fascicularis) ventral horn harbors small- to medium-sized neurons in lamina VII as well as a dense network of fibers in laminae IX and VII that contain calbindin D28k (calbindin)-like immunoreactivity. The highest frequency of immunoreactive (IR) cell bodies was found at the levels of the cervical and lumbar intumescences. Furthermore, rostrocaudally oriented calbindin-IR fibers were encountered in the ventral and ventrolateral funiculi throughout the whole length of the cord, with the highest density at cervical and lumbar intumescences. Analysis at the EM level revealed calbindin-IR terminals in contact preferentially with dendrites of variable size and occasionally also large cell bodies, presumably belonging to motoneurons, in the lateral motor nucleus. The location of calbindin-IR neurons, as well as the distribution and ultrastructural characteristics of the calbindin-IR axonal system, makes it highly likely that these neurons are Renshaw cells that mediate recurrent inhibition to motoneurons.
\end{abstract}

In two classical papers, Renshaw described the existence of recurrent inhibition of motoneurons (Renshaw, 1941) and identified interneurons that probably mediated this inhibition (Renshaw, 1946). Later, Eccles, Fatt, and Koketsu (Eccles et al., 1954) concluded that the recurrent inhibition of motoneurons was mediated via the cholinergic terminals of the recurrent motor axon collaterals. These terminals were proposed to excite the interneurons described by Renshaw, thus denoted Renshaw cells, which in turn would inhibit motoneurons by a synaptic mechanism that was blocked by the glycine antagonist strychnine. Later, both GABA and glycine were postulated to be involved in the recurrent inhibitory loop (Cullheim and Kellerth, 1981; van den Pol and Gorcs, 1988). Direct evidence for glycine as a transmitter in the recurrent inhibitory loop has recently been provided by Fyffe (1991a). He has demonstrated in the cat that physiologically identified Renshaw cells, intracellularly stained

\footnotetext{
Received May 6, 1991; revised Oct. 2, 1991; accepted Oct. 7, 1991.

This study was supported by grants from the Swedish Medical Research Council (Projects 04X-2887 and 12X-6815), Marcus and Amalia Wallenbergs Minnesfond Goljes Minnesfond, Anders Otto Swärds Minnesfond, Swedish Society for Medical Research, and the Karolinska Institute. The excellent technical assistance of Mss. $\mathrm{K}$. Aman and W. Hiort is gratefully acknowledged, and we express sincere gratitude to Pharmacia Opthalmics (Dr. A. Härfstrand and Ms. A. S. Holst) for generously providing the monkeys. We thank Professor M. R. Celio, Institute of Histology, University of Fribourg, Switzerland, for supply of calbindin antiserum.

Correspondence should be addressed to Dr. Ulf Arvidsson, Department of Anatomy, Karolinska Institute, P.O. Box 60400, S-10401 Stockholm, Sweden. Copyright (C) 1992 Society for Neuroscience $0270-6474 / 92 / 120718-11 \$ 05.00 / 0$
}

with HRP and later examined at the EM level after a postembedding immunogold procedure, contained glycine-like immunoreactivity (-LI) in synaptic terminals apposing dendrites in the motor nuclei. By combining physiological and anatomical techniques, it has been concluded that the position of Renshaw cell bodies is confined to a restricted area ventromedial to the main motor nuclei in Rexed's (Rexed, 1954) lamina VII (Willis and Willis, 1964; Thomas and Wilson, 1965; Jankowska and Lindström, 1971; Walmsley and Tracey, 1981; Lagerbäck and Kellerth, 1985b; Fyffe, 1990), and detailed mapping of their axonal trajectories (Lagerbäck and Kellerth, 1985b) has shown a consistence with the distribution of recurrent inhibition disclosed with electrophysiological technique (Jankowska and Smith, 1973).

As a part of a larger study concerned with Renshaw cells in the cat and monkey, we here report that calbindin-immunoreactive (IR) neurons, fibers, and terminals in the monkey, by virtue of their anatomy, may be Renshaw cells. Calbindin is a $D$ vitamin-dependent protein first isolated by Wassermann and Taylor (1966) in the chicken intestinal mucosa. Later studies have shown that calbindin belongs to a family of soluble proteins (calcium-binding protein) capable of sequestering intracellular calcium (Heizmann, 1984), and calbindin-LI has been identified in discrete neuronal populations of the CNS in many species (Celio and Heizmann, 1981; Heizmann, 1984; Gerfen et al., 1985; Celio, 1990; Sequier et al., 1990). In the rat, a location of calbindin-IR cell bodies similar to the one found here has been reported by Antal et al. (1990) and Celio (1990).

\section{Materials and Methods}

Three young adult gray monkeys (Macaca fascicularis) were deeply anesthetized with pentobarbital $(40 \mathrm{mg} / \mathrm{kg})$, and a transcardial perfusion was made with cold isotonic saline for 1-2 min followed by a fixative containing $4 \%$ paraformaldehyde and picric acid $(0.4 \%)$ in $0.1 \mathrm{M}$ phosphate buffer (Pease, 1962; Zamboni and de Martino, 1967). The spinal cords were quickly removed, placed in fresh fixative for $1-2 \mathrm{hr}$ at $4^{\circ} \mathrm{C}$, and then transferred to a $10 \%$ sucrose buffer solution containing $0.01 \%$ sodium azide and $0.02 \%$ bacitracin (Bayer, Leverkusen, Germany) overnight. Spinal cord segments from cervical, thoracic, lumbar, and sacral levels were cut in 14- $\mu \mathrm{m}$-thick transverse and frontal ("horizontal") sections in a cryostat (Dittes, Heidelberg, Germany) and processed for the indirect immunofluorescence method (Coons, 1958). Briefly, the sections were rehydrated in $0.1 \mathrm{M}$ PBS and then incubated with mouse monoclonal anti-calbindin antibodies (1:400 dilution; Celio et al., 1990) for $24-48 \mathrm{hr}$ at $4^{\circ} \mathrm{C}$. After several rinses in phosphate buffer, the sections were incubated with fluorescein isothiocyanate (FITC)-conjugated sheep anti-mouse antibodies ( $1: 10$ dilution; Amersham Ltd., Amersham, UK). All incubations with secondary antisera were performed in a humid atmosphere at $37^{\circ} \mathrm{C}$ for $30 \mathrm{~min}$. All sera used in this study contained $0.3 \%$ Triton X-100 (Hartman et al., 1972). The sections were mounted in a mixture of glycerol/PBS (3:1) containing $0.1 \% p$-phenylenediamine 
in order to retard fading (Johnson and Nogueria Araujo, 1981; Platt and Michael, 1983) and examined in a Nikon Mikrophot-FX microscope equipped with epifluorescence and proper filter combinations for FITC (filter cube B-2A, $510 \mathrm{~nm}$ dichroic mirror, $450-490 \mathrm{~nm}$ excitation filter, $520-560 \mathrm{~nm}$ barrier filter, and $550 \mathrm{~nm}$ extra barrier short-pass filter). All micrographs were taken with black-and-white (Kodak Tri$\mathrm{X}$ ) or color films (Kodak Ektachrome).

Material from another two monkeys was taken for light (LM) and electron microscopical analysis. Tissue, fixed as described above but with the addition of $0.5 \%$ glutaraldehyde, was processed for the peroxidase-antiperoxidase (PAP) method (Sternberger et al., 1970). After postfixation ( $90 \mathrm{~min}$ ) and saturation in $10 \%$ sucrose buffer solution, the tissue blocks were rinsed in Tris-buffered saline (TBS), sectioned in a Vibratome $(40-50 \mu \mathrm{m})$, and thereafter treated with $1 \%$ sodium borohydride (Willingham, 1983). Immunolabeling was performed on a shaking table at room temperature for 12-18 hr with the same mouse monoclonal antiserum as that used for immunofluorescence histochemistry but at a dilution of 1:2000. Goat anti-mouse bridge-antibody (Dakopatts, Copenhagen, Denmark) and mouse (PAP)-antibody complex (Sternberger-Meyer Immunocytochemical Inc., Jarrettsville, MD) were used at dilutions of 1:60 and 1:600, respectively. For the location of peroxidase activity, sections were incubated with diaminobenzidine (Sigma, St. Louis, $\mathrm{MO}$ ) and $0.3 \% \mathrm{H}_{2} \mathrm{O}_{2}$ dissolved in TBS. Specimens processed for light microscopy (LM) had $0.5 \%$ Triton X-100 added to the incubation solutions. LM sections were mounted in Entellan (Merck, Darmstadt, Germany) on gelatinized glass and covered with glass slips. Tissue sections for electron microscopy were, after rinsing, transferred to Marchi's osmium solution, dehydrated in alcohol, and embedded in Epon between plastic foils. Selected sections were reembedded in Epon, trimmed, and cut in a series of ultrathin sections on an Ultratome (LKB, Stockholm, Sweden), mounted on one-hole Formvar-coated nickel slot grids, and counterstained with uranyl acetate and lead citrate. The sections were analyzed and photographed in a 301 Philips electron microscope.

Measurements of immunoreactive cell body diameters were made in the LM at $1250 \times$ magnification with an eyepiece micrometer. The mean cell body diameter was calculated from the major and minor diameters of the largest ellipsoid that could fit within the boundaries of the cell body outline. In addition, varicosities from randomly selected immunoreactive fibers in the lumbar lateral motor nucleus were measured. Varicosities were defined as outbulgings having at least twice the diameter of the adjacent parts of the axon (cf. Cullheim and Kellerth, 1978). Similar swellings originating from $\alpha$-motoneuron axon collaterals have previously been identified in the electron microscope as genuine synaptic boutons (see, e.g., Cullheim et al., 1977; Lagerbäck et al., $1981 \mathrm{a}, \mathrm{b})$. Furthermore, a detailed ultrastructural analysis of 41 randomly selected terminals was also performed. The terminals were traced in serial ultrathin sections until a synaptic specialization could be observed. For each terminal, parameters as terminal size, type and size of postsynaptic element(s), and synapse type (symmetric/asymmetric) were determined.

\section{Results}

Sections, prepared for indirect immunofluorescence and PAP immunohistochemistry, revealed an extensive labeling of cell bodies, dendrites, and axons (Figs. 1-3). Fibers and cell bodies containing calbindin-LI could be found in the dorsal horn, intermediate gray, and ventral horn (Fig. $1 A$ ). However, the main interest of this study has been focused on the IR cell bodies and fibers in the ventral horn. The largest number of calbindin-IR cell bodies was found in the lumbar (Figs. $1 A-C, 2 B, 3 C, G$ ) and cervical intumescences (Figs. $2 A, 3 A, E$ ) of the spinal cord. The cell bodies were almost exclusively encountered in the ventral part of lamina VII, but at thoracic and sacral spinal cord levels IR cells could also be found in the motor nucleus (Fig. $3 B, D, F, H$ ). Sectioning of the spinal cord in the frontal plane revealed a column of calbindin-IR cell bodies oriented rostrocaudally (Fig. 2). The cell bodies were round to fusiform and had, as judged from LM, a mean body diameter of $23.3 \pm 3.8 \mu \mathrm{m}(n=76$; range, $14.5-36.8 \mu \mathrm{m}$ ).

The rather dense fiber network containing calbindin-LI in the
Table 1. LM quantitative data on calbindin-IR cells in lamina VII and IR axonal varicosities in the motor nucleus

\begin{tabular}{lll} 
& Cell bodies & $\begin{array}{l}\text { Axonal } \\
\text { varicosities }\end{array}$ \\
\hline Mean diameter $\pm \mathrm{SD}(\mu \mathrm{m})$ & $23.3 \pm 3.8$ & $1.6 \pm 0.45$ \\
Range & $14.5-36.8$ & $0.5-3.3$ \\
Number & 76 & 147 \\
\hline
\end{tabular}

ventral horn was essentially confined to the motor nucleus and the ventral part of lamina VII, especially at the levels of the intumescences (Figs. $1 A-C, 3 A, C$ ). The density of axon fibers and varicosities was highest in the medioventral part, gradually decreasing dorsolaterally through the motor nuclei (Fig. $1 A, B$ ). Only few labeled terminals with a classical varicose appearance could also be seen in close apposition to large cell bodies, probably motoneurons (Fig. $1 B, D-E$ ). The size of the terminals, as judged from LM level, ranged from 0.5 to $3.3 \mu \mathrm{m}$ (mean $\pm \mathrm{SD}$, $1.6 \pm 0.4 \mu \mathrm{m} ; n=147)$.

Large numbers of rostrocaudally oriented calbindin-IR fibers were encountered in the ventral funiculus of the white matter, throughout the whole length of the spinal cord (Fig. $3 A-D$ ). IR axons were also seen in the ventrolateral funiculus, especially at thoracic and sacral spinal cord levels (Fig. 3B,C). The number of IR fibers showed a variation consistent with the number of IR cells and the extent of the fiber network in the motor nucleus found at each of the cervical, thoracic, lumbar, and sacral levels.

Calbindin-positive cells located in lamina VII and identified at the LM level were examined in the EM (Fig. $4 A, A^{\prime}$ ). Such examination revealed an electron-dense peroxidase reaction product in cell bodies, dendrites, and axonal boutons. The PAP reaction product in the cell bodies (Fig. $4 B$ ) and dendrites (Fig. $4 C$ ) appeared as a coating of organelles such as mitochondria, cytoskeletal components such as tubuli, and the inner membrane of cyto- and dendrolemma. Calbindin-IR cell bodies (Fig. $4 B$ ) and dendrites (Fig. 4C) were contacted by normally appearing synaptic boutons.

Calbindin-IR terminals were observed in both lamina IX and lamina VII. Morphological data were obtained from 41 randomly selected calbindin-IR terminals in the lateral motor nucleus (lamina IX). The mean diameter of the IR terminals varied between 0.8 and $2.2 \mu \mathrm{m}$ (mean $\pm \mathrm{SD}, 1.4 \pm 0.4$ ). A majority of the vesicles in the terminals were spherical (Fig. $5 B, C$ ); however, scant pleomorphic vesicles could also be verified (Fig. $5 C$ ). The vesicle diameter was approximately 50-75 $\mathrm{nm}$. More than $75 \%$ of the synapses were typed as symmetrical. Clear asymmetric synapses (Fig. $5 \mathrm{~A}$ ) could also be demonstrated in a few cases. Out of 36 terminals that could be classified, 33 made contact with one to three dendrites each (Fig. $6 B, C$ ) and 3 with cell bodies of large neurons (size $>45 \mu \mathrm{m}$ ) (Fig. 6A). The size of the dendrites varied between 0.4 and $5.2 \mu \mathrm{m}$ in diameter (mean $\pm \mathrm{SD}, 2.0 \pm 0.9 \mu \mathrm{m}$ ). Nine calbindin-IR terminals made contact with more than one postsynaptic element. The LM and EM data are summarized in Tables 1 and 2.

\section{Discussion}

Recurrent inhibition of motoneurons has been demonstrated throughout the length of the cat spinal cord (Renshaw, 1941; Eccles et al., 1954, 1961; Wilson et al., 1960; Hultborn et al., 1971; Kirkwood et al., 1981; Hahne et al., 1988). Anatomical studies of electrophysiologically identified Renshaw cells, intra- 

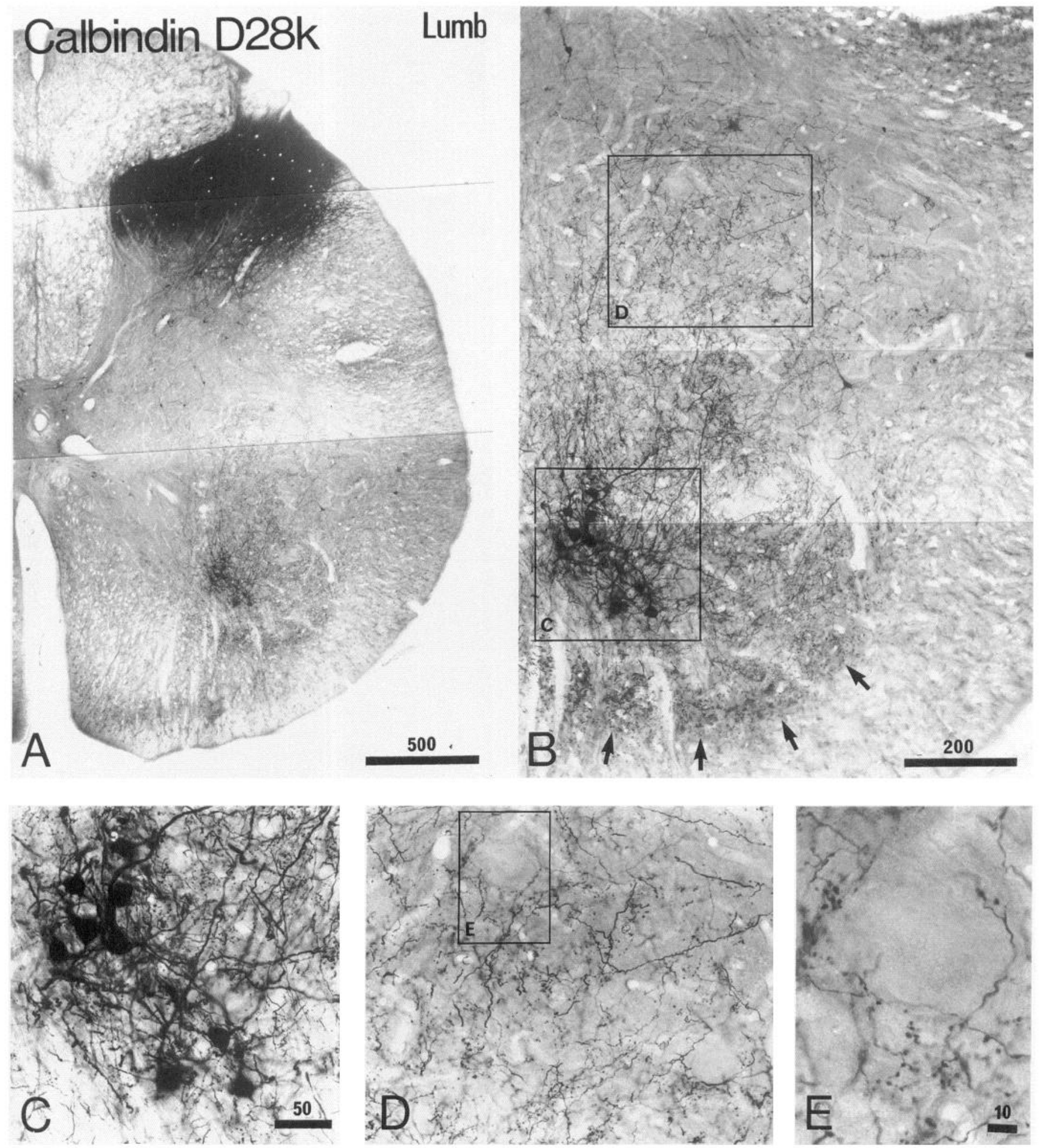

Figure 1. Light micrographs of a Vibratome section from the monkey lumbar ( Lumb) spinal cord after calbindin D28k PAP immunohistochemistry. $A$, Photomontage illustrating the distribution of calbindin-IR cell bodies and fibers in the lower lumbar spinal cord. $B$, Photomontage showing the ventral horn at higher magnification. Note the presence of the extensive fiber system within the motor nucleus. Arrows in $B$ point at the area where the rostrocaudally oriented calbindin-IR fibers are located. Rectangles in $B$ are shown at higher magnification in $C$ and $D$, where calbindin-IR cell bodies within lamina VII and IR terminals in the dorsal part of the motor nucleus are shown, respectively. Note that many fibers have a typical varicose appearance. Rectangle in $D$ is shown at higher magnification in $E$, where many fibers and varicosities can be seen in the vicinity of a large cell body, presumably representing an $\alpha$-motoneuron. Scale bar in $C$ is also valid for $D$. All scale bars indicate $\mu \mathrm{m}$. 


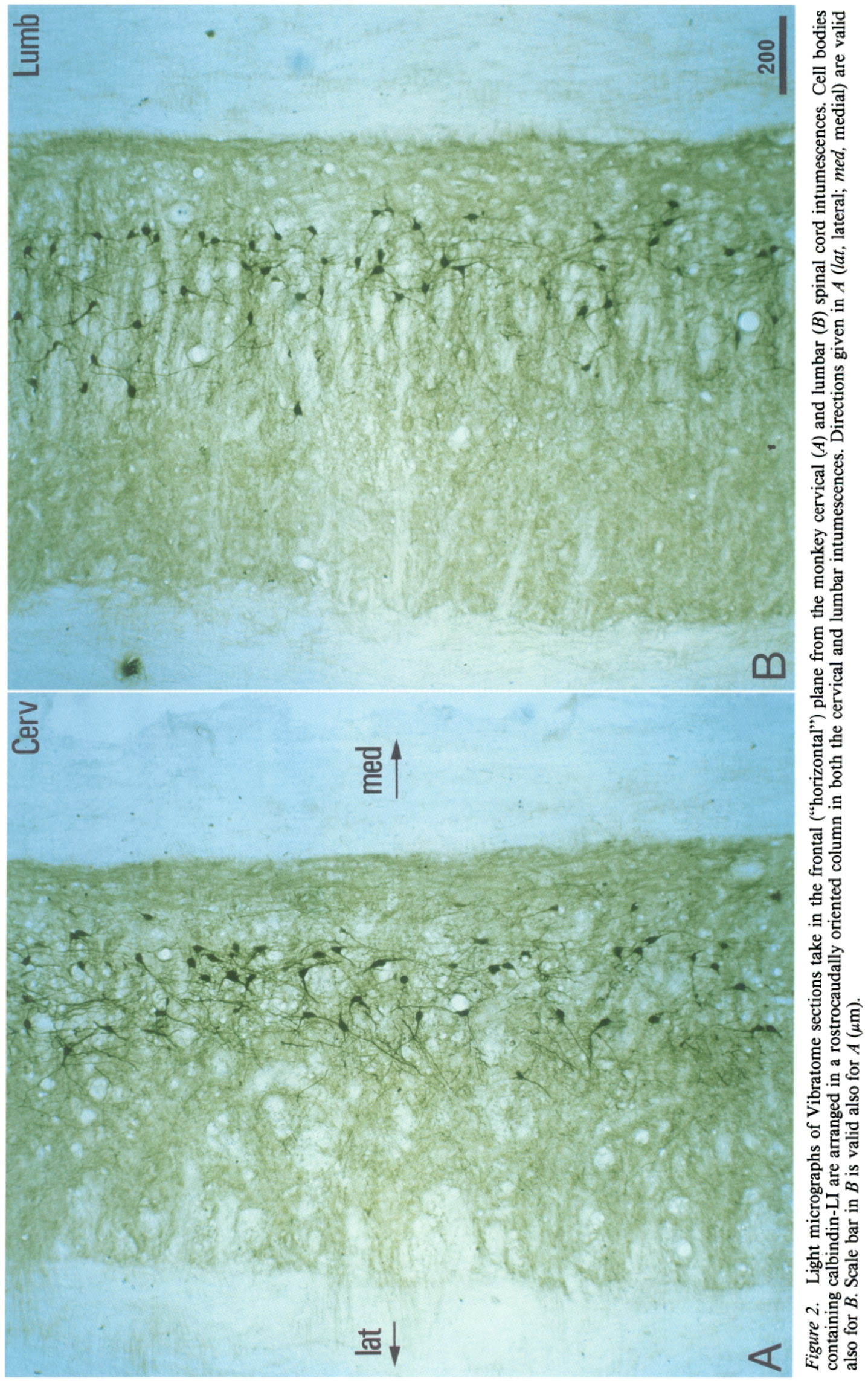



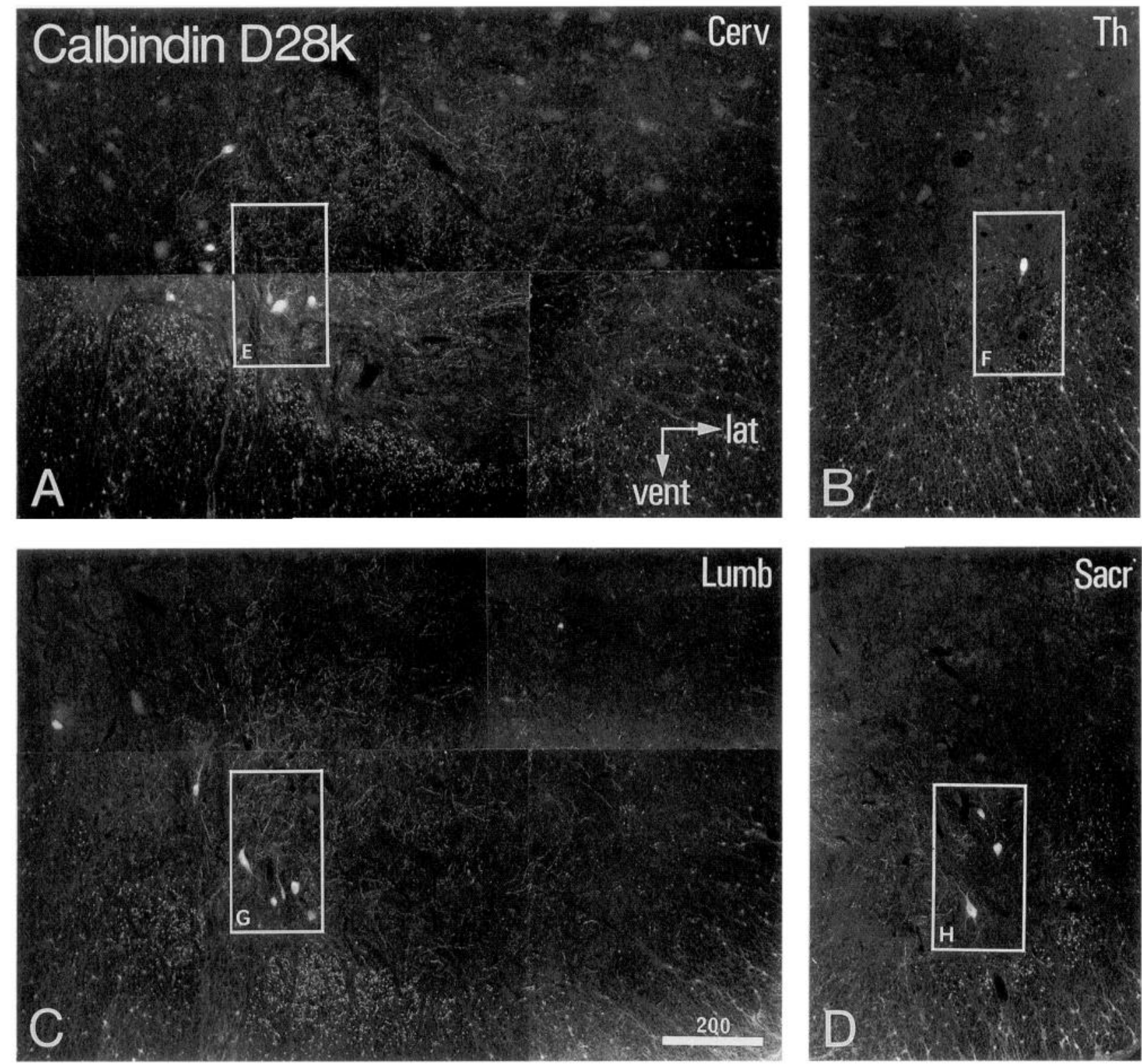

Lumb
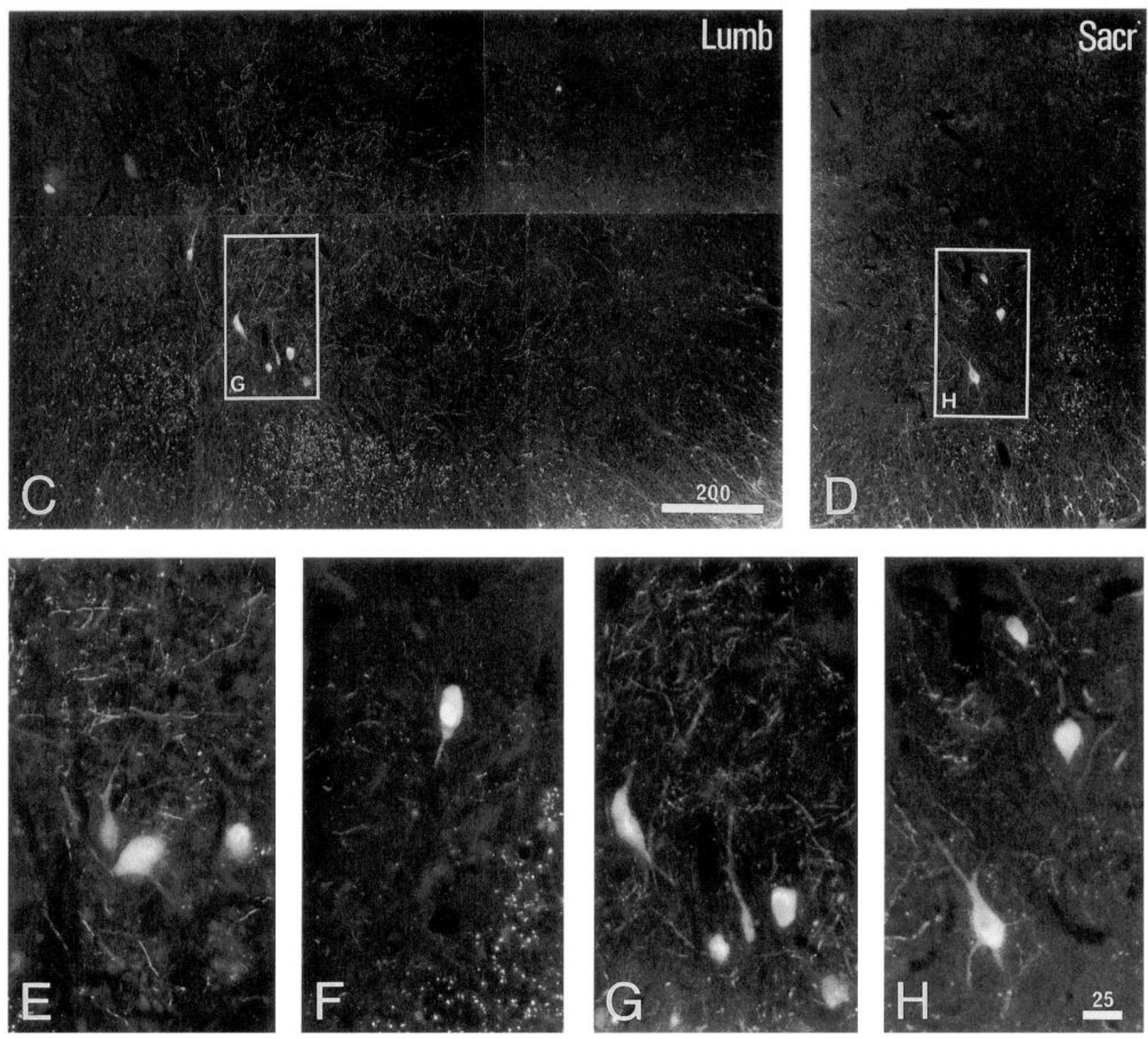
cellularly labeled with dye markers or HRP (Willis and Willis, 1964; Thomas and Wilson, 1965; Jankowska and Lindström, 1971; Walmsley and Tracey, 1981; Lagerbäck and Kellerth, 1985b; Fyffe, 1990), have revealed that these cells are almost invariably located in the ventral portion of lamina VII, medial to the main lateral motor nucleus, but can occasionally also be found within the motor nucleus (Fyffe, 1990). The size of the positive neurons in this study (mean, $23.3 \mu \mathrm{m}$ ) is in accordance with those obtained in cat (Lagerbäck et al., 1985b: mean, 29.4 $\mu \mathrm{m}$; Fyffe, 1990: mean, $27 \mu \mathrm{m}$ ). The main axons of the Renshaw cells enter the ventral funiculus just medial to the motor axon exit zone, where they take on a rostrocaudal course for several millimeters and "en passant" give off a variable number of collaterals throughout their course (Lagerbäck and Kellerth, 1985a). This pattern is consistent with the distribution of axons from single Renshaw cells, as determined electrophysiologically (Jankowska and Smith, 1973). Morphological studies have also shown that the axon collateral terminals of Renshaw cells are found both in the motor nucleus (85\%) and to some extent in lamina VII (15\%) (Lagerbäck and Kellerth, 1985a; Fyffe, 1991b). A few percent of the the terminals in the motor nucleus are demonstrated in close apposition to the motoneuron cell bodies (Lagerbäck and Kellerth, 1985a; Fyffe, 1991b). Evidently, these previous anatomical descriptions given for Renshaw cells and their axonal system in the cat show a conspicuous similarity to the calbindin-IR system found here in the monkey spinal cord, indicating that Renshaw cells may contain calbindin-LI. It could be advocated that the calbindin-IR neurons are interneurons in long propriospinal pathways, coordinating forc- and hindlimb movements (Barilari and Kuypers, 1969; Miller et al., 1973; Molenaar and Kuypers, 1978), since such propriospinal neurons have a similar location with respect to cell body and course of the axon. However, the number of calbindin-IR axons in the ventral funiculus showed a variation at different levels of the spinal cord, which grossly paralleled both the local number of IR cells and the extent of the fiber network in the gray matter. This variability provides evidence that the calbindin-IR neurons participate in local reflex pathways rather than in long propriospinal pathways. However, it cannot be excluded that part of the calbindin-IR terminals found in the motor nucleus have origin from other sources. Philippe and Droz (1989) demonstrated that Ia primary afferents innervating muscle spindles in the chick contain calbindin-LI. Primary sensory afferents containing calbindin are thus also a possible source of input to the motor nucleus. However, no calbindin-positive fiber crossing the intermediate gray on its way to the motor nucleus in the ventral horn could be verified here; thus, a major contribution of Ia primary afferents containing calbindin-LI seems less likely. Another possible source giving rise to input of calbindin-IR fibers in the motor nucleus is the interneurons found in the intermediate gray. However, no axons from these cells projecting into the motor nucleus could be found. Furthermore, the calbindin-IR axons at hand in the ventral aspect of the lateral funiculus could represent axons from a descending tract, and
Table 2. EM data on calbindin-IR axon terminals and postsynaptic elements in the motor nucleus

\begin{tabular}{lcll} 
& \multicolumn{3}{c}{$\begin{array}{l}\text { Postsynaptic } \\
\text { elements }\end{array}$} \\
\cline { 2 - 4 } & Terminals $^{a}$ & Dendrite & Soma \\
\hline Mean diameter \pm SD $(\mu \mathrm{m})$ & $1.4 \pm 0.4$ & $2.0 \pm 0.9$ & $>45$ \\
Range & $0.8-2.2$ & $0.4-5.2$ & - \\
Number & 36 & 43 & 3 \\
$\%$ & 100 & 93.5 & 6.5 \\
Symmetric complex & $>75 \%$ & & \\
Number of postsynaptic elements & & & \\
$\quad$ per terminal: & & & \\
1 & $27 / 36$ & & \\
2 & $8 / 36$ & & \\
3 & $1 / 36$ & & \\
\hline
\end{tabular}

${ }^{a}$ Only terminals with a postsynaptic element(s) have been included. In five further cases, the postsynaptic element could not be classified.

thus a contribution of calbindin-IR terminals found in the motor nucleus with a supraspinal origin is also a possibility. It should be emphasized, however, that the course of preterminal calbindin-IR axons, which also in many cases could be followed in their continuity to cell bodies in lamina VII, strongly speaks for an origin from the cells described in this article.

The presence of calbindin-IR cell bodies in the ventral part of lamina VII in the rat was demonstrated by Antal et al. (1990) and Celio (1990). These authors also suggested them to be Renshaw cells but did not provide any data with respect to the axonal system of the calbindin-IR cells.

Calcium is of fundamental importance for neuronal firing, and calcium-binding proteins, such as calbindin, may therefore play a role in this event. Calbindin has attracted increasing attention since it is, like parvalbumin, expressed in discrete subsets of neurons in the CNS (Celio and Heizmann, 1981; Heizmann, 1984; Gerfen et al., 1985; Celio, 1990; Sequier et al., 1990). So far, mapping studies have failed to associate calbindin expression with a particular transmitter type, in contrast to parvalbumin, which often seems to be colocalized with GABA in several regions of the CNS (Kirkwood et al., 1981; Celio, 1986; Kawaguchi et al., 1987; Stichel et al., 1988). These proteins may serve to buffer free calcium and thereby interfere with the activation of calcium-dependent conductances or calciumdependent enzymatic reactions that may disturb the cell activity. Onc such cxample is the calcium-dcpendent potassium conductance responsible for the afterhyperpolarization (AHP) (Krnjević et al., 1975). AHP is a prominent spike frequency regulator, prolonging the spike interval. A reduction of the size of the AHP, by calbindin, should therefore increase the maximal firing frequency of the neuron. Accordingly, the expression of parvalbumin and calbindin in neurons has been suggested to be a property of high-frequency spiking neurons (Heizmann, 1984; Celio, 1986; Kawaguchi et al., 1987). In this context, it is of obvious interest that Renshaw cells may fire at very high fre-

\footnotetext{
Figure 3. Immunofluorescence micrographs of the ventral horn of cervical $(C e r v, A)$, thoracic $(T h, B)$, lumbar $(\operatorname{Lumb}, C)$, and sacral $(\operatorname{Sacr}, D)$ spinal cord levels after incubation with calbindin D28k antiserum. Rectangles in $A-D$ are shown at higher magnification in $E-H$. $A-D$, Cell bodies containing calbindin-LI can be seen at all levels. Note also the presence of fibers within laminae VII and IX as well as in the ventral funiculus. Directions given in $A$ (vent, ventral; lat, lateral) are valid for all plates. Scale bar in $C$ is valid for $A-D$ and bar in $H$ is valid for $E-H$ (both indicatc $\mu \mathrm{m})$.
} 

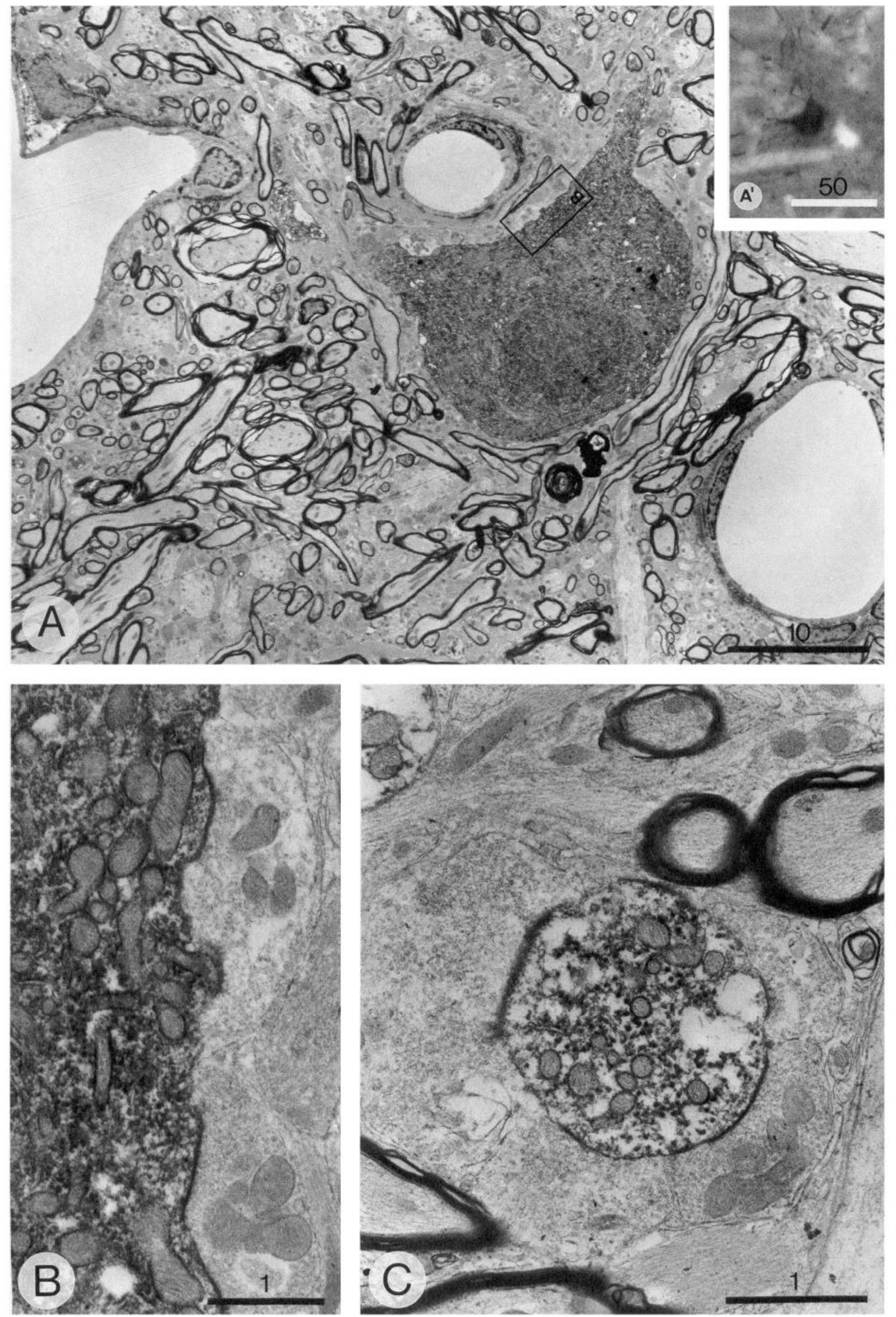

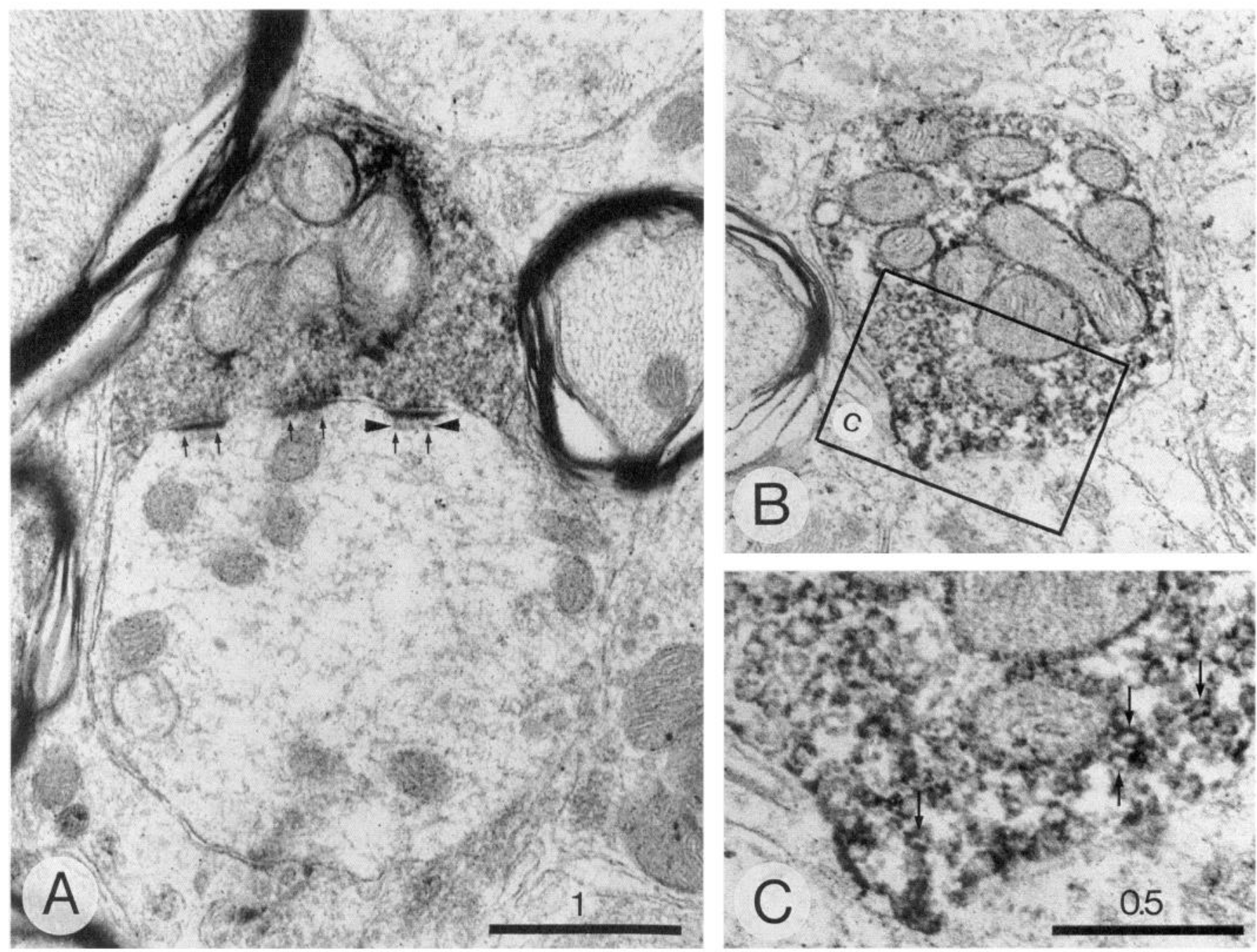

Figure 5. Electron micrographs of calbindin-IR varicosities from ventral horn lamina IX in the lower lumbar segment of the monkey spinal cord. $A$, A labeled bouton with three active zones making asymmetric contacts (arrows) with a dendrite. Note postsynaptic dense bodies (Taxi bodies, arrowheads). $B$ and $C$, Micrographs taken from a thin section to illustrate the shape of the vesicles in a calbindin-IR varicosity. Note in $C$ (high magnification of rectangle in $B$ ) that some of vesicles are pleomorphic (arrows). Scale bar in $A$ is also valid for $B$ (indicating $\mu \mathrm{m}$ ).

quencies, up to $1000 \mathrm{~Hz}$ (see, e.g., Eccles et al., 1954). The presence of calbindin in axon terminals as demonstrated here could then be important to handle the high frequency of action potentials invading the terminal. An efficient buffering mechanism for calcium by a cytosolic protein in the terminals may be necessary to ensure a pause in transmitter release before the invasion of the next action potential in trains of very high frequency (see also Blaustein, 1988). Accordingly, the calcium buffering by calbindin may subserve two different purposes in the soma-dendritic region and the axon terminal, respectively, both of which are relevant for the transfer of a high-frequency message.

The large cell bodies in lamina IX are with all probability motoneurons (Rexed, 1954), and the vast majority of the dendrite profiles, especially those with large diameter, should also be of motoneuron origin (Ulfhake and Kellerth, 1981). Our EM observations showed that the postsynaptic profiles to calbindinLI boutons in the motor nucleus were almost invariably dendrites. A few contacts were also demonstrated on large cell bodies in the lateral motor nucleus. The range of postsynaptic dendrite diameters found here indicates that calbindin-IR boutons are distributed on both proximal and distal dendrite branches. Considering the calbindin-IR boutons in contact with cell bodies and proximal dendrites, these contacts have a distribution consistent with the location inferred by the observed effects of current and $\mathrm{Cl}^{-}$injection at the soma on the recurrent IPSPs in motoneurons (Burke et al., 1971).

More than $75 \%$ of the contacts in this study were defined as symmetrical, in accordance with the classical concept that inhibitory synapses form symmetric contacts. However, clear

Figure 4. Electron micrographs of calbindin-IR cell body (light microscopically shown in $\mathrm{A}^{\prime}$ ) and a dendrite from lamina VII in the lower lumbar segment of the monkey spinal cord. $A$, The PAP reaction product is seen throughout the cytoplasm of the labeled cell body. Rectangle in $A$ is shown at higher magnification in $B . B$. Two unlabeled boutons making contact with the cell body can be seen. $C$, A labeled dendrite surrounded by several unlabeled boutons that make synaptic contact is demonstrated. All scale bars indicate $\mu \mathrm{m}$. 

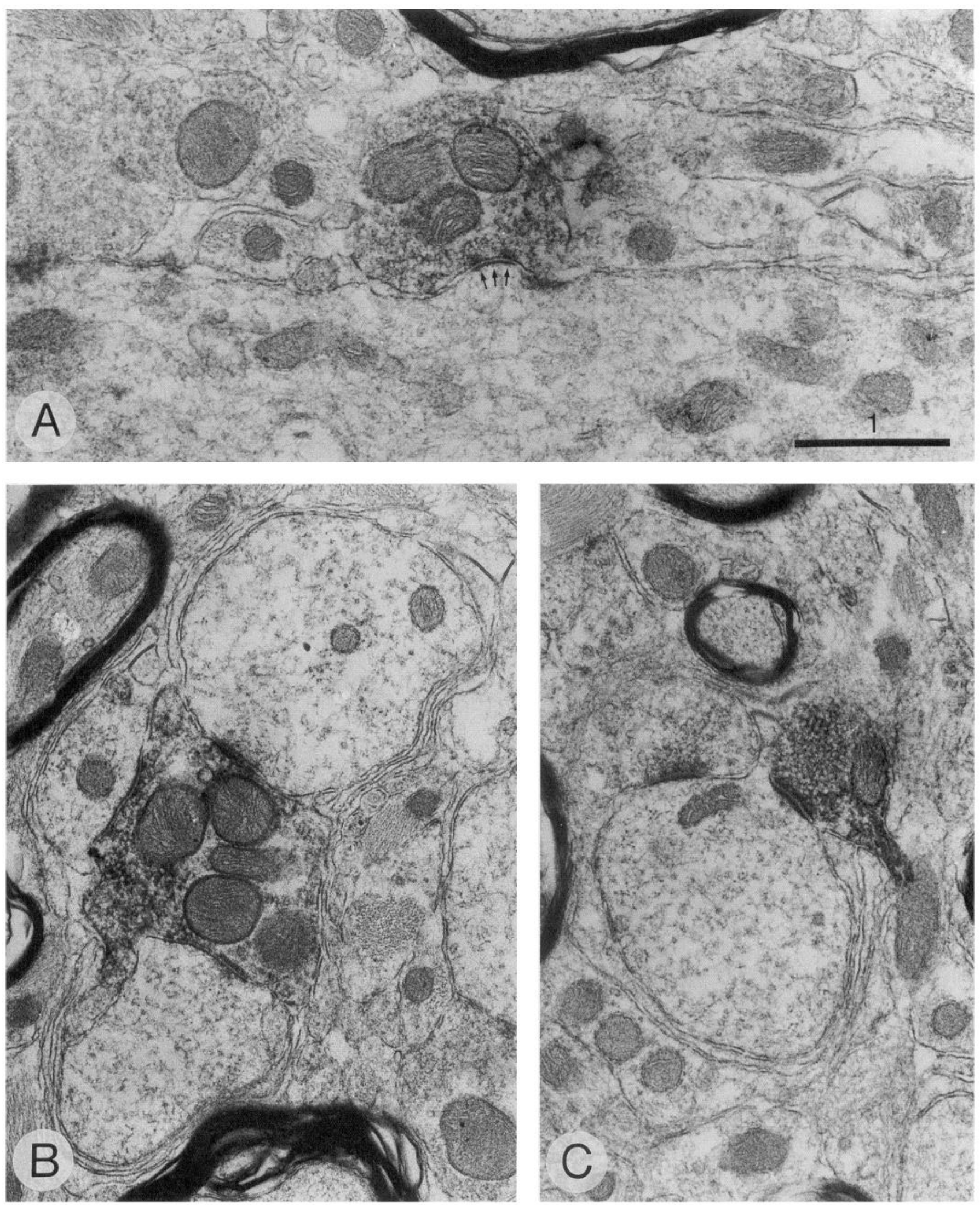

Figure 6. Electron micrographs of calbindin-IR varicosities from ventral horn lamina IX in the lower lumbar segment of the monkey spinal cord. $A$, A labeled bouton that makes contact (arrows) with a large cell body, presumably an $\alpha$-motoneuron, is seen. $B$ and $C$, Labeled boutons making synaptic contacts with dendrites. Scale bar in $A$ is also valid for $B$ and $C$ (indicating $\mu \mathrm{m}$ ). 
asymmetric synapses were also encountered. A similar fine structure has been found for GABAergic terminals in the spinal cord (McLaughlin et al., 1975), striatum, and globus pallidus (Ribak et al., 1979) as well as in the inferior olive (Sotelo et al., 1986). Thus, a symmetric contact does not seem to be a prerequisite for an inhibitory synapse.

\section{References}

Antal M, Freund TF, Polgar E (1990) Calcium-binding proteins, parvalbumin- and calbindin-D 28k-immunoreactive neurons in the rat spinal cord and dorsal root ganglia: a light and electron microscopic study. J Comp Neurol 295:467-484.

Barilari MG, Kuypers HGJM (1969) Propriospinal fibers interconnecting the spinal enlargements in the cat. Brain Res 14:321-330.

Blaustein MP (1988) Calcium transport and buffering in neurons. Trends Neurosci 11:438-443.

Burke RE, Fedina L, Lundberg A (1971) Spatial synaptic distribution of recurrent and group Ia inhibitory systems in cat spinal motoneurones. J Physiol (Lond) 214:305-326.

Celio MR (1986) Parvalbumin in most gamma-aminobutyric acidcontaining neurons of the rat cerebral cortex. Science 231:995-997.

Celio MR (1990) Calbindin D-28k and parvalbumin in the rat brain. Neuroscience 35:375-475.

Celio MR, Heizmann CW (1981) Calcium-binding protein parvalbumin as a neuronal marker. Nature 293:300-302.

Celio MR, Baier W, Schärer L, Gregersen HJ, de Viragh PA, Norman AW (1990) Monoclonal antibodies directed against the calcium binding protein calbindin D-28k. Cell Calciunı 11:599-602.

Coons AH (1958) Fluorescent antibody methods. In: General cytochemical methods (Danielli JF, ed), pp 399-422. New York: Academic.

Cullheim S, Kellerth J-O (1978) A morphological study of the axons and recurrent axon collaterals of cat sciatic $\alpha$-motoneurones after intracellular staining with horseradish peroxidase. J Comp Neurol 178:537-558.

Cullheim S, Kellerth J-O (1981) Two kinds of recurrent inhibition of cat spinal $\alpha$-motoneurones as differentiated pharmacologically. $\mathrm{J}$ Physiol (Lond) 312:209-224.

Cullheim S, Kellerth J-O, Conradi S (1977) Evidence for direct synaptic interconnections between cat spinal $\alpha$-motoneurons via the recurrent axon collaterals: a morphological study using intracellular injections of horseradish peroxidase. Brain Res 132:1-10.

Eccles JC, Fatt P, Koketsu K (1954) Cholinergic and inhibitory synapses in a pathway from motor-axon collaterals to motoneurones. J Physiol (Lond) 126:524-562.

Eccles JC, Eccles RM, Iggo A, Ito M (1961) Distribution of recurrent inhibition among motoneurones. J Physiol (Lond) 159:479-499.

Fyffe REW (1990) Evidence for separate morphological classes of Renshaw cells in the cat's spinal cord. Brain Res 536:301-304.

Fyffe REW (1991a) Glycine-like immunoreactivity in synaptic boutons of identified inhibitory interneurons in the mammalian spinal cord. Brain Res 547:175-179.

Fyffe REW (1991b) Spatial distribution of recurrent inhibitory synapses on spinal motoneurons in the cat. J Neurophysiol 65:11341149.

Gerfen CR, Baimbridge KG, Miller JJ (1985) The neostriatal mosaic: compartmental distribution of calcium-binding protein and parvalbumin in the basal ganglia of the rat and monkey. Proc Natl Acad Sci USA 82:8780-8784.

Hahne M, Illert M, Wietelmann D (1988) Recurrent inhibition in the cat distal forelimb. Brain Res 456:188-192.

Hartman BK, Zide D, Udenfriend S (1972) The use of dopamine $\beta$ hydroxylase as a marker for the noradrenergic pathways of the central nervous system in the rat. Proc Natl Acad Sci USA 69:2722-2726.

Heizmann CW (1984) Parvalbumin, an intracellular calcium-binding protein; distribution, properties and possible roles in mammalian cells. Experientia 40:910-921.

Hultborn H, Jankowska E, Lindström S (1971) Recurrent inhibition of interneurons monosynaptically activated from group Ia afferents. J Physiol (Lond) 215:613-636.

Jankowska E, Lindström S (1971) Morphological identification of Renshaw cells. Acta Physiol Scand 81:428-430.
Jankowska E, Smith DO (1973) Antidromic activation of Renshaw cells and their axonal projections. Acta Physiol Scand 88:198-214.

Johnson DG, Nogueria Araujo GMC (1981) A simple method of reducing the fading of immunofluorescence during microscopy. J Immunol Methods 43:349-350.

Kawaguchi Y, Katsumaru H, Kosaka T, Heizmann CW, Hama K (1987) Fast spiking cells in the rat hippocampus (CA1 region) contain the calcium-binding protein parvalbumin. Brain Res 416:369-374.

Kirkwood PA, Sears TA, Westgaard RH (1981) Recurrent inhibition of intercostal motoneurones in the cat. J Physiol (Lond) 319:111130.

Krnjević K, Phil E, Werman R (1975) Evidence for $\mathrm{Ca}^{2+}$-activated $\mathrm{K}^{+}$ conductance in cat spinal motoneurons from intracellular EGTA injections. Can J Physiol Pharmacol 53:1214-1218.

Lagerbäck P-Å, Kellerth J-O (1985a) Light microscopic observations on cat Renshaw cells after intracellular staining with horseradish peroxidase. I. The axonal system. J Comp Neurol 240:359-367.

Lagerbäck P-Å, Kellerth J-O (1985b) Light microscopic observations on cat Renshaw cells after intracellular staining with horseradish peroxidase. II. The cell bodies and dendrites. J Comp Neurol 240:368376.

Lagerbäck P-Å, Ronnevi L-O, Cullheim S, Kellerth J-O (1981a) An ultrastructural study of the synaptic contacts of $\alpha$-motoneurone axon collaterals. I. Contacts in lamina IX and with identified alpha-motoneurone dendrites in lamina VII. Brain Res 207:247-266.

Lagerbäck P-Å, Ronnevi L-O, Cullheim S, Kellerth J-O (1981b) An ultrastructural study of the synaptic contacts of $\alpha$-motoneurone axon collaterals. II. Contacts in lamina VII. Brain Res 222:29-41.

McLaughlin BJ, Barber R, Saito R, Roberts E, Wu J-Y (1975) Immunocytochemical localization of glutamate decarboxylase in rat spinal cord. J Comp Neurol 164:305-322.

Miller S, Reitsma DJ, Van der Meche FGA (1973) Functional organization of long ascending propriospinal pathways linking lumbosacral and cervical segments in the cat. Brain Res 62:169-188.

Molenaar I, Kuypers HGJM (1978) Cells of origin of propriospinal fibers and of fibers ascending to supraspinal levels. A HRP study in cat and rhesus monkey. Brain Res 152:429-450.

Pease PC (1962) Buffered formaldehyde as a killing agent and primary fixative for electron microscopy. Anat Rec 142:342.

Philippe E, Droz B (1989) Calbindin-immunoreactive sensory neurons of dorsal root ganglion project to skeletal muscle in the chick. J Comp Neurol 283:153-160.

Platt JL, Michael AF (1983) Retardation of fading and enhancement of intensity of immunofluorescence by $p$-paraphenylenediamine. $\mathrm{J}$ Histochem Cytochem 31:840-842.

Renshaw B (1941) Influence of discharge of motoneurons upon excitation of neighbouring motoneurons. J Neurophysiol 4:167-183.

Renshaw B (1946) Central effects of centripetal impulses in axons of spinal ventral roots. J Neurophysiol 9:191-204.

Rexed B (1954) A cytoarchitectonic atlas of the spinal cord in the cat. J Comp Neurol 100:297-379.

Ribak CE, Vaughn JE, Roberts E (1979) The GABA neurons and their axon terminals in rat corpus striatum as demonstrated by GAD immunocytochemistry. J Comp Neurol 187:261-284.

Sequier JM, Hunziker W, Andressen C, Celio MR (1990) Calbindin D-28k protein and mRNA localization in the rat brain. Eur $J$ Neurosci 2:1118-1126.

Sotelo C, Gotow T, Wassef M (1986) Localization of glutamic-aciddecarboxylase-immunoreactive axon terminals in the inferior olive of the rat, with special emphasis on anatomical relations between GABAergic synapses and dendrodendritic gap junctions. J Comp Neurol 252:32-50.

Sternberger LA, Hardy PH, Cuculis JJ, Meyer HG (1970) The unlabelled antibody enzyme method of immunohistochemistry. Preparation and properties of soluble antigen-antibody complex (horseradish-peroxidase-anti-horseradish peroxidase) and its use in the identification of spirochetes. J Histochem Cytochem 18:315-333.

Stichel CC, Singer W, Heizmann CW (1988) Light and electron microscopic immunohistochemical localization of parvalbumin in the dorsal lateral geniculate nucleus of the cat: evidence for coexistence with GABA. J Comp Neurol 268:29-37.

Thomas RC, Wilson VJ (1965) Precise localization of Renshaw cells with a new marking technique. Nature 206:211-213.

Ulfhake B, Kellerth J-O (1981) A quantitative light microscopic study 
of the dendrites of the cat spinal $\alpha$-motoneurones after intracellular staining with horseradish peroxidasc. J Comp Ncurol 202:571-583.

van den Pol AN, Gorcs T (1988) Glycine and glycine receptor immunoreactivity in brain and spinal cord. J Neurosci 8:472-492.

Walmsley B, Tracey DJ (1981) An intracellular study of Renshaw cells. Brain Res 223:170-175.

Wasserman RH, Taylor AN (1966) Vitamin D3 induced calcium binding protein in chick intestinal mucosa. Science 152:791-793.

Willingham MC (1983) An alternative fixation-processing method for preembedding ultrastructural immunocytochemistry of cytoplasmic antigens: the GBS (glutaraldehyde-borohydride-saponin) procedure. J Histochem Cytochem 31:791-798.

Willis WD, Willis JC (1964) Location of Renshaw cells. Nature 204: 1214-1215.

Wilson VJ, Talbot WH, Diecke FPJ (1960) Distribution of recurrent facilitation and inhibition in cat spinal cord. J Neurophysiol 23:144 153.

Zamboni L, de Martino C (1967) Buffered picric acid formaldehyde. A new rapid fixative for electron microscopy. J Cell Biol 35:148A. 